Viktoriia Petrenko, Doctor of Economic Sciences, Associate Professor, Kherson State University, 27, University str., Kherson, 73000, Ukraine ORSID: 0000-0001-8336-7665; ResearcherID: V-7363-2017

Alla Karnaushenko, Candidate of Economic Sciences, Kherson State Agrarian University, 23, Stritenskaya str., Kherson, 73000, Ukraine ORCID: 0000-0003-1813-2792;

ResearcherID: A-3777-2019

\title{
INFLUENCE OF TRANSFORMATION PROCESSES IN THE ECONOMY FOR THE DEVELOPMENT OF TOURISM IN UKRAINE
}

Today, tourist activity of different countries is at the peak of its development. Ukraine also has significant recreational and tourism potential, but there are many factors that hold it back. The paper examines the current state of development of the tourism industry in Ukraine, the actual and planned indicators of the development of the industry have been analyzed using the "Strategy for the development of tourism and resorts for the period up to 2026», including the amount of revenues to the budget from tourism fee and the dynamics of tourist flows. On the basis of the actual state, the main reasons that hinder tourist activity in Ukraine have been identified. The proposed measures will help to strengthen the financial potential, improve the investment attractiveness of the enterprises of the industry and create conditions for effective development of economic entities.

Key words: tourism, tourist enterprises, tourist activity.

Relevance of research topic. According to the forecasts of the World Tourism Organization, tourism will occupy a leading position in the field of world export in the next ten years. Recently, tourism and recreation in Ukraine are gaining popularity. As a matter of fact, Ukraine has great potential and possesses almost all resort resources: natural thermal waters, hydro-resources, therapeutic mud, mixed coniferous forest and the sea coast. Almost every region of the country has its own unique natural and recreational resources, which have become the basis for the sanatorium-and-healthresort areas. The current state of formation and realization of the existing tourism potential, given the Ukrainian tourist services market, can be described as uneven 
(Hulich, 2005). This situation is caused by the concentration of several attractive regions in the tourist services market, the prerequisites for tourism development in which «lie on the surface», and their own city is an infrastructure centre and its circumference is often impossible or illogical due to geographical and administrative location, or because of marketing actions and their results.

Formulation of the problem. Ukraine, with its significant tourism and recreational potential, can join the most visited countries in the world. But despite all the favourable territorial and climatic conditions for conducting tourist activities, there are many problems in Ukraine. Economic and political instability, neglected transportation infrastructure, outdated facilities of resorts and poorly qualified service personnel adversely affect the performance and financial state of tourism entities. In the course of economic activity, economic entities need to keep an eye on their existing financial needs, including the search for sufficient financial resources and their rational use and opportunities for their effective functioning and development.

Analysis of recent researches and publications. Hryniv L. (1989), Hulych O. (2005), Odum, C. (2018) investigated the problems of tourist and recreational sphere and territorial recreational complexes, and also identified problems of development of recreational regions, tourist and recreational resources, factors of regulation of ecologically balanced development of resort and recreational areas etc., without using the financial components of these problems.

Pikkemaat, B. and Zehrer, A. (2016) paid attention to the innovative potential of small tourism firms in their works, as well as to estimating relationships between the experience of service and innovations for small family businesses in the tourism industry. An important element in the development of tourism enterprises is financing and gaining financial independence and autonomy. Mohammed Bala Banki and Hairul Nizam Ismail (2015) have developed a concept for alternative financing of small tourism businesses. Panasiuk A. (2016) places emphasis on the range of financing of the regional tourism economy in the perspective of EU financing.

Literature review indicates the importance of the development of tourism activities for both the state and employment of the population, and the subjects of tourism business must achieve high financial security, financial independence and stability in their activity.

Presenting main material. The global economic crises have been the driving factors for the development of tourism businesses in different countries, which have started to use the existing economic potential in international tourism as a specific source of foreign exchange resources. Even in the highly developed tourist area of the world, Europe, not all of the tourism business opportunities are fully realized. Local and regional authorities are promoting their own territories to assist the tourism industry in adapting to the current difficult economic situation by diversifying and developing more sustainable industry-specific business models. The purpose of each 
country's current tourism policy is to turn tourism into a competitive, modern, sustainable and highly profitable business sector.

European experience shows that local and regional authorities, on whom sustainable management of tourist destinations depends, must play a key role in the development of tourism activities. Tourism is one of the most profitable sectors of the economy, as investment efficiency can be equated with oil and gas, refining and motor industries (Griniv, 1989). At the beginning of the $21^{\text {st }}$ century, in terms of income, tourism ranked third among the leading industries in the world economy. In many countries and regions, tourism is a major source of income. In terms of the number of employees, the tourism industry has become one of the largest in the world - it employs over 260 million people, i.e. every $10^{\text {th }}$ employed person. Global travel revenues account for more than $\$ 500$ billion annually (Odum, 2018). Western Europe and the USA have the highest profits.

The «Strategies for the development of tourism and resorts for the period up to 2026» adopted by the Cabinet of Ministers of Ukraine in 2017, identify the tourism activity as one of the priority areas for the development of the economy and culture of Ukraine. According to this strategy, the main objective is to create favourable conditions for the development of tourism and resorts taking into account international standards of quality and European values, transformation of the tourism industry into a highly profitable and competitive sphere of activity, which contributes to improving the quality of life of the population, harmonious development and promotion of Ukrainian tourism in the world (Table 1).

Table 1

\section{Indicators for the development of tourism and resorts in Ukraine taking into account the Industry Development Strategy up to 2026}

\begin{tabular}{|l|l|l|l|l|l|l|}
\hline \multicolumn{1}{|c|}{$\begin{array}{c}\text { Name of development } \\
\text { indicator }\end{array}$} & 2016 & 2017 & 2018 & 2019 & 2022 & 2026 \\
\cline { 2 - 7 } & 13.3 & 14.4 & 14.2 & $\begin{array}{l}\text { increase by } \\
1.5 \text { times }\end{array}$ & $\begin{array}{l}\text { increase by } \\
2 \text { times }\end{array}$ & $\begin{array}{l}\text { increase } \\
\text { by } 2.5 \\
\text { times }\end{array}$ \\
\hline $\begin{array}{l}\text { Number of foreign } \\
\text { tourists entering Ukraine, } \\
\text { million people }\end{array}$ & 6.8 & 3.5 & 4.3 & $\begin{array}{l}\text { increase by } \\
1.5 \text { times }\end{array}$ & $\begin{array}{l}\text { increase by } \\
3 \text { times }\end{array}$ & $\begin{array}{l}\text { increase } \\
\text { by } 5 \text { times }\end{array}$ \\
\hline $\begin{array}{l}\text { Number of subjects of } \\
\text { tourist activity, thousand } \\
\text { units }\end{array}$ & 54.1 & 70.2 & 90.7 & $\begin{array}{l}\text { increase by } \\
2 \text { times }\end{array}$ & $\begin{array}{l}\text { increase by } \\
5 \text { times }\end{array}$ & $\begin{array}{l}\text { increase } \\
\text { by } 10 \\
\text { times }\end{array}$ \\
\hline $\begin{array}{l}\text { Amounts of revenues to } \\
\text { the local budgets from the } \\
\text { payment of tourism fee, } \\
\text { million UAH }\end{array}$ & & & & & \\
\hline
\end{tabular}




\begin{tabular}{|l|l|l|l|l|l|l|}
\hline \multicolumn{1}{|c|}{$\begin{array}{c}\text { Name of development } \\
\text { indicator }\end{array}$} & 2016 & 2017 & 2018 & 2019 & 2022 & 2026 \\
\cline { 2 - 7 } & 2.50 & 3.50 & 4.22 & $\begin{array}{l}\text { increase by } \\
2 \text { times }\end{array}$ & $\begin{array}{l}\text { increase by } \\
5 \text { times }\end{array}$ & $\begin{array}{l}\text { increase } \\
\text { by } 10 \\
\text { times } \\
\text { budget revenues (taxes } \\
\text { and fees) from the activity } \\
\text { of tourist entities, billion } \\
\text { UAH }\end{array}$ \\
\hline $\begin{array}{l}\text { Number of jobs in } \\
\text { tourism, thousand persons }\end{array}$ & 9.6 & 10.6 & 11.9 & $\begin{array}{l}\text { increase by } \\
1.5 \text { times }\end{array}$ & $\begin{array}{l}\text { increase by } \\
3 \text { times }\end{array}$ & $\begin{array}{l}\text { increase } \\
\text { by } 5 \text { times }\end{array}$ \\
\hline $\begin{array}{l}\text { Number of domestic } \\
\text { tourists, thousand persons }\end{array}$ & 453 & 477 & 456.8 & $\begin{array}{l}\text { increase by } \\
\text { 2 times }\end{array}$ & $\begin{array}{l}\text { increase by } \\
3 \text { times }\end{array}$ & $\begin{array}{l}\text { increase } \\
\text { by } 5 \text { times }\end{array}$ \\
\hline $\begin{array}{l}\text { Number of sightseers, } \\
\text { thousand persons }\end{array}$ & 125.5 & 136.9 & 145.2 & $\begin{array}{l}\text { increase by } \\
1.5 \text { times }\end{array}$ & $\begin{array}{l}\text { increase by } \\
2 \text { times }\end{array}$ & $\begin{array}{l}\text { increase } \\
\text { by } 2.5 \\
\text { times }\end{array}$ \\
\hline
\end{tabular}

Source: compiled by authors based on materials of the Cabinet of Ministers of Ukraine

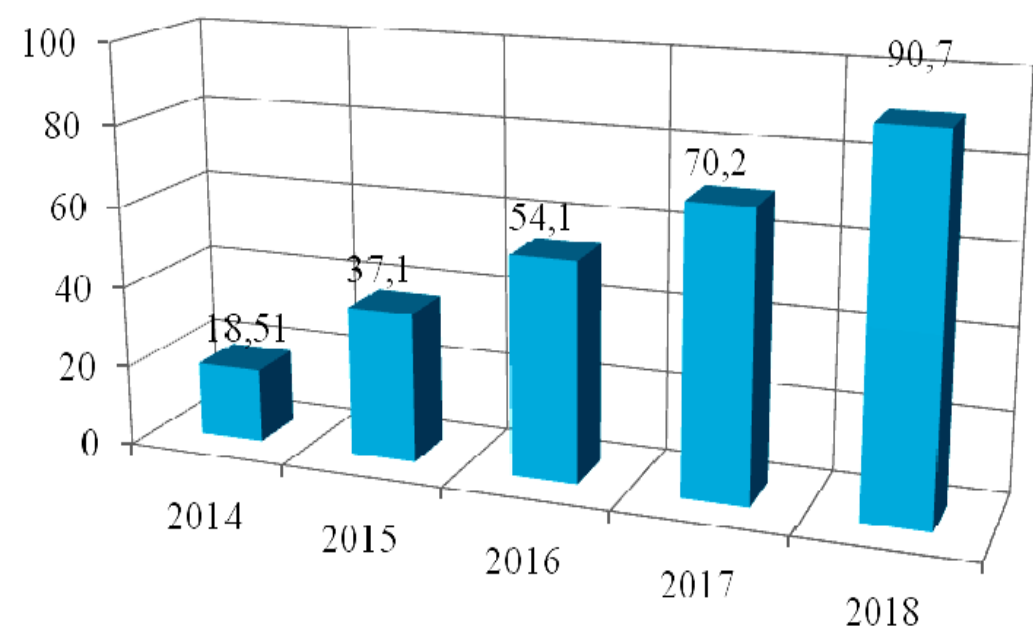

Figure 1. Amount of revenues from tourism fee for the period from 2014 to 2018

Source: compiled by authors based on materials of the State Statistics Service of Ukraine

In 2018, the revenues from tourism fee amounted to UAH 90.7 million, which is $29,2 \%$ more than in 2017 . At the same time, the increase in payment of the tourism fee was 30\% in 2017 as compared with 2016.

There is a positive trend in the payment of tax payments to the State Budget of Ukraine by enterprises engaged in tourism. In 2018, the amount of tax payments from legal entities and individuals - entrepreneurs engaged in tourism activities amounted 
to 4,222.2 million UAH, which is $20,7 \%$ more than in 2017. At the same time, the amount of payments from legal entities increased by $19,2 \%$, and from individuals entrepreneurs - by $38,1 \%$.

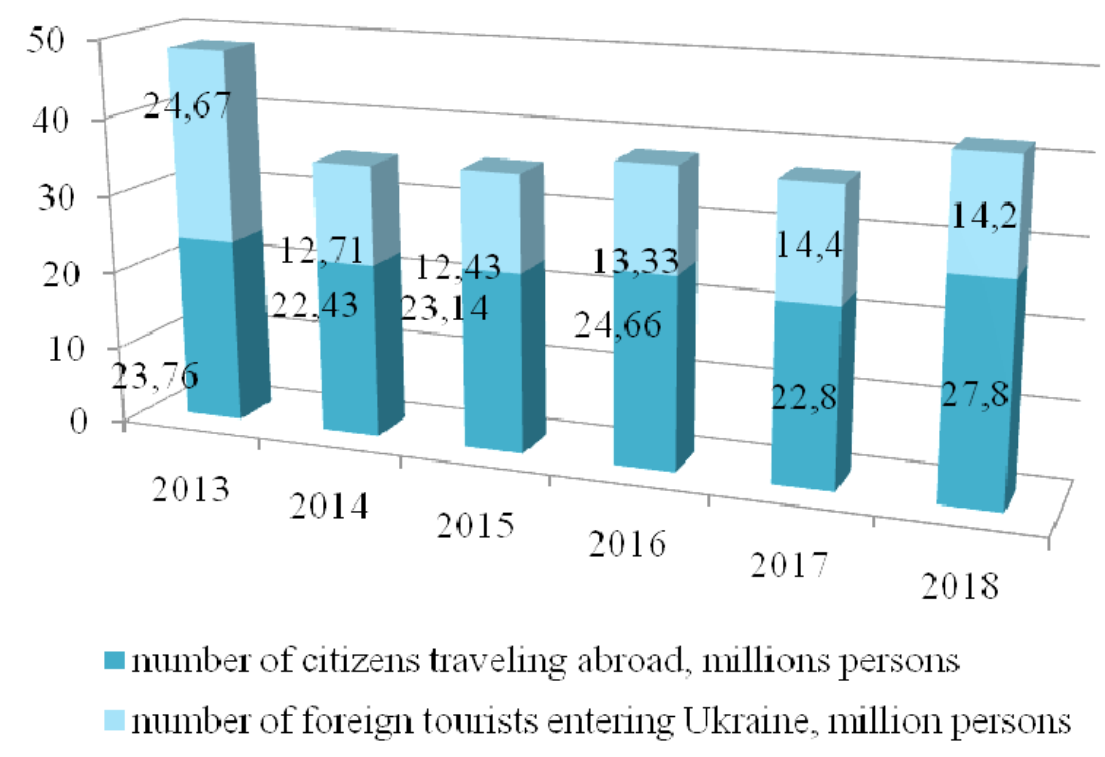

Figure 2. Dynamics of tourist flows for the period from 2013 to 2018

Source: compiled by authors based on materials of the State Statistics Service of Ukraine

According to the State Statistics Service of Ukraine, there is a positive trend in tourist flows, but the number of foreign tourists entering Ukraine remains insignificant as compared with other developed tourist countries.

In this regard, the main reasons, which restrain the foreign tourists of coming to Ukraine, should be highlighted:

first, the poor tourism infrastructure - most hotels and sanatoriums were built at the time of the USSR, and they have low comfort levels;

secondly, the low level of tourist service and the low number of skilled personnel in this field;

thirdly, the transport problem, expensive Low-cost carriers and poor road conditions;

fourthly, the military conflict in Ukraine, an unstable political situation and higher level of criminality in tourist regions;

Having the great tourism potential of the regions, Ukrainian tourist operators need to rebuild and make more comfortable hotels and sanatoriums, recruit and train employees, thus improving the quality of service. In this regard, tourism enterprises need to find additional financial resources.

The analysis of the current state of development of the financial potential of tourism enterprises revealed that one of the main problems that hinder its effective 
development is the violation of financing of the business entity. We believe that in order to increase the financial potential of tourism enterprises by improving its financing, it is necessary to solve the following main tasks: to expand the range of financial resources of the enterprise; to increase the revenue part of the enterprise budget; to optimize enterprise costs (Table 2).

Table 2

\section{Progress made by the entities of tourism activity in 2017 and 2018, million UAH}

\begin{tabular}{|c|c|c|c|c|c|c|c|c|}
\hline & \multirow[b]{2}{*}{ 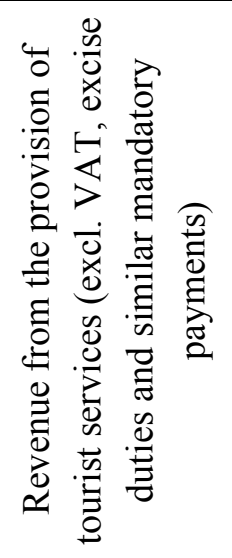 } & \multirow[b]{2}{*}{ 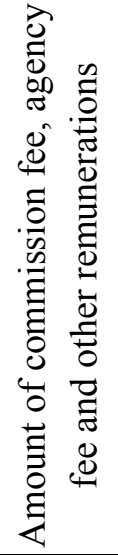 } & \multirow[b]{2}{*}{ 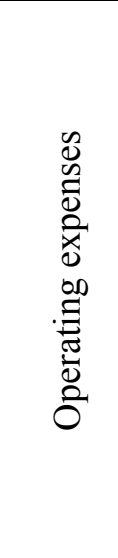 } & \multicolumn{5}{|c|}{ Including } \\
\hline & & & & 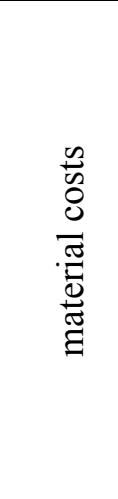 & 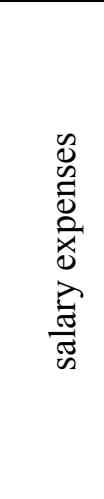 & 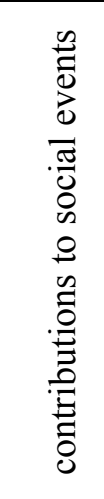 & 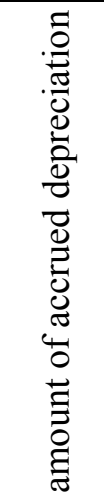 & 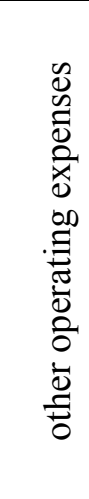 \\
\hline 2017 & 20.695 & 0,902 & 16.894 & 13.568 & 0.541 & 0.117 & 0.710 & 1.958 \\
\hline 2018 & 21.069 & 0.969 & 17.925 & 14.386 & 0.567 & 0.123 & 0.729 & 2.118 \\
\hline Growth $(+,-)$ & +1.8 & +7.4 & +6.1 & +6.0 & +4.8 & +5.1 & +2.7 & +8.1 \\
\hline \multicolumn{3}{|c|}{ Operating profitability in 2017} & 1.225 & & & & & \\
\hline \multicolumn{3}{|c|}{ Operating profitability in 2018} & 1.175 & & & & & \\
\hline
\end{tabular}

Source: calculated by authors according to the State Statistics Service of Ukraine

In general, the progress made by the entities of tourism activity, show positive growth in all indicators.

Equally important is the attraction of investments in the activities of the tourism enterprise, which will increase its financial potential. The needs of tourism enterprises in the available additional sources of financing have an increasing trend, and the preliminary analysis revealed the downward nature of this process. We believe that project financing will help to attract investments, including foreign ones, into the financing of tourism enterprises. In the current context, to attract investment, it is necessary to improve the image of the economy at the state level in order to intensify the process.

In addition, interesting and reliable projects that attract investors must be produced within the business entities to attract foreign capital. It is also advisable to focus on an expanded range of services provided. In particular, we consider 
it advisable to create an investment project to attract foreign investments for sale of apartments by the example of the Georgian company ORBI GROUP (Petrenko \& Karnaushenko, 2017).

It is worth noting that in recent years, the vector of domestic tourism products development has shifted towards finding new destinations. The signing of the Association Agreement of Ukraine with the EU Member States affected the overall geography of inbound tourists (Table 3).

Table 3

TOP-11 countries, whose citizens visit Ukraine most often,
thousand persons

\begin{tabular}{|l|l|l|l|l|l|l|l|l|l|}
\hline $\begin{array}{c}\text { Names of the } \\
\text { countries } \\
\text { whose citizens } \\
\text { visit Ukraine } \\
\text { most often }\end{array}$ & 2010 & 2011 & 2012 & 2013 & 2014 & 2015 & 2016 & 2017 & 2018 \\
\cline { 2 - 11 } & & & & & & & & & \\
\hline $\begin{array}{l}\text { Russian } \\
\text { Federation }\end{array}$ & 7.900 .4 & 9018.5 & 9526.7 & 10284.8 & 2363.0 & 1231.0 & 1473.6 & 1464.8 & 1539.2 \\
\hline Moldova & 4063.5 & 4071.8 & 4849.1 & 5418.0 & 4368.4 & 4393.5 & 4296.4 & 4435.7 & 4436.7 \\
\hline Belarus & 3058.0 & 2644.0 & 3091.8 & 3353.7 & 1592.9 & 1891.5 & 1822.3 & 2727.6 & 2666.7 \\
\hline Poland & 2089.6 & 1720.1 & 1404.1 & 1259.2 & 1123.9 & 1156.0 & 1195.1 & 1144.2 & 1097.1 \\
\hline Hungary & 944.8 & 862.1 & 742.4 & 771.0 & 874.2 & 1070.0 & 1269.7 & 1119.4 & 915.8 \\
\hline Romania & 910.5 & 735.2 & 791.3 & 877.2 & 584.8 & 763.2 & 774.6 & 791.1 & 740.5 \\
\hline Slovakia & 610.0 & 564.3 & 476.6 & 424.3 & 416.2 & 412.5 & 410.5 & 366.2 & 314.0 \\
\hline Germany & 227.7 & 231.7 & 274.1 & 253.3 & 131.2 & 154.5 & 171.1 & 209.4 & 237.9 \\
\hline USA & 125.9 & 127.9 & 134.1 & 134.7 & 81.7 & 108.3 & 138.0 & 153.8 & 184.3 \\
\hline Uzbekistan & 105.5 & 141.1 & 185.5 & 235.4 & 158.0 & 68.8 & 135.4 & 22.8 & 93.8 \\
\hline Israel & 82.0 & 120.2 & 107.1 & 120.9 & 101.8 & 149.6 & 217.2 & 261.1 & 317.8 \\
\hline
\end{tabular}

Source: compiled by authors on the basis of data of the State Migration Service of Ukraine

It should be noted that the biggest reserve for increasing the financial potential of tourism enterprises lies in the development of innovative activities, which can also be enhanced by attracting investments and introducing international quality and service standards into their business. 
Considering the fact, that the border countries are traditionally the leaders in the visit of Ukraine and make up $82.3 \%$ of the total inbound tourist flow in 2018 , the fluctuations of the tourist flow indicators mainly depend on these countries.

Visits to Ukraine by nationals of border countries decreased, while of nonborder ones increased: Britain by $47.3 \%$, China by $38.8 \%$, Lithuania by $23.4 \%$, Israel by $21.7 \%$, the United States by $19.7 \%$, Czech Republic by $16.0 \%$, Italy by $15.4 \%$, Germany by $13.3 \%$, France by $9.2 \%$, Bulgaria by $7.9 \%$.

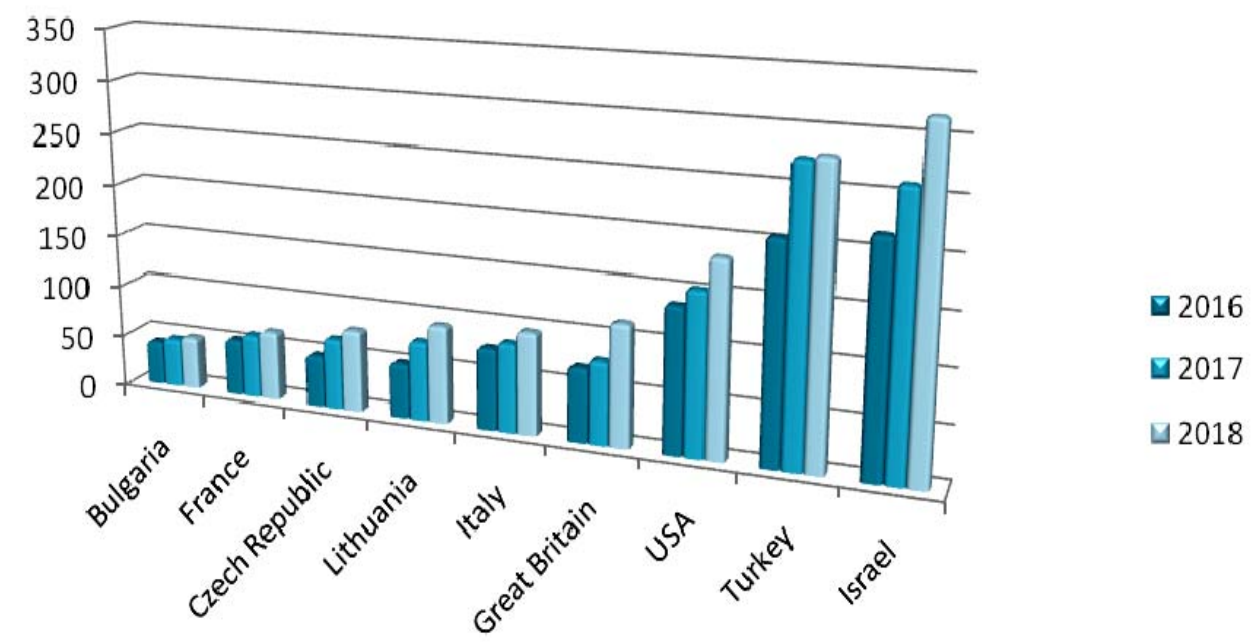

Figure 3. Dynamics of growth of entry of citizens from non-border countries, thousand persons

Source: Compiled by authors on the basis of data of the State Migration Service of Ukraine

The process of globalization of the economy and the integration of the tourism sector into the international economy encourages the entities of this industry to develop innovative directions that can ensure competitiveness. Based on the natural and climatic and tourist potential of the country, green tourism, which is widely popularized in developed countries is one of the priority directions in Ukraine.

Conclusion. The analysis of the state and development of tourism in Ukraine indicates the positive dynamics of its development. Satisfying the growing needs of the country's population in tourism and recreation is becoming an important state task. Not without reason, the National Tourism Organization of Ukraine announced 2020 the year of rural tourism. This decision is associated with the need to develop and implement mechanisms for the sustainable development of tourism, as well as ensuring the socio-economic well-being of the regions. Indeed, currently there is a disproportion in the regional development of tourism, which require special study. 


\section{REFERENCES}

1. Griniv, L. S. (1989). Territorialnyi khozraschetnyi mekhanizm upravleniia kurortami (na primere balneologicheskikh kurortov Karpatskogo regiona USSR) [Territorial self-supporting mechanism of resort management (on the example of balneological resorts of the Carpathian region of the Ukrainian SSR)]. Lviv: Knyhodruk

2. Hulich, O. I. (2005). Faktory regulirovaniia ekologicheski sbalansirovannogo razvitiia kurortnoozdorovitelnykh territorii [Factors of regulation of ecologically balanced development of health resort and recreational territories]. Ekonomika Ukrainy, 5, 78-82.

3. Odum, C. (2018) Evaluation of Potential Ecotourism Attractions for Sustainable Tourism Development in Anambra State, Nigeria. Doctoral Dissertation Summary. European Journal of Tourism Research 20, pp. 134-136.

4. Pikkemaat, B. and Zehrer, A. (2016). Innovation and service experiences in small tourism family firms. International Journal of Culture, Tourism and Hospitality Research, 10 (4), 343-360.

5. Petrenko, V., Karnaushenko, A. (2017). Jont enterprises in foreign trade activity of Ukraine. Baltic Journal of Economic Studies. 3 (5), 203-207.

6. Panasiuk, A. (2016). Finansowanie regionalnej gospodarki turystycznej ze środków Unii Europejskiej w perspektywach finansowych 2007-2013 i 2014-2020, Ekonomiczne Problemy Usług, 4, 275-288.

7. The official site of Cabinet of Ministers of Ukraine (2019). Government Portal. Retrieved from: https://www.kmu.gov.ua/

8. The official site of State Statistics Service of Ukraine (2019). State Statistics Service of Ukraine. Retrieved from: http://www.ukrstat.gov.ua/

9. The official site of State Migration Service of Ukraine (2019). Dmsu.gov. Retrieved from: https://dmsu.gov.ua/ 